\title{
Essential Oils of Aromatic and Medicinal Plants as Botanical Biocide for Management of Coconut Eriophyid Mite (Aceria guerreronis Keifer)
}

\author{
Susmita Patnaik, ${ }^{1}$ Kadambini Rout, ${ }^{1}$ Sasmita Pal, ${ }^{1}$ Prasanna Kumar Panda, ${ }^{1}$ \\ Partha Sarathi Mukherjee, ${ }^{2}$ and Satyabrata Sahoo' \\ ${ }^{1}$ Natural Products Department, Institute of Minerals and Materials Technology (IMMT), Bhubaneswar 751013, India \\ ${ }^{2}$ Advanced Materials Technology, Institute of Minerals and Materials Technology (IMMT), Bhubaneswar 751013, India \\ Correspondence should be addressed to Susmita Patnaik, susmitapatnaik007@gmail.com
}

Received 1 September 2010; Revised 30 December 2010; Accepted 11 April 2011

Academic Editor: G. B. Dunphy

Copyright (C) 2011 Susmita Patnaik et al. This is an open access article distributed under the Creative Commons Attribution License, which permits unrestricted use, distribution, and reproduction in any medium, provided the original work is properly cited.

The present study investigated the efficiency of essential oils extracted from different aromatic and medicinal plant sources on Aceria guerreronis Keifer, one of the serious pests of coconut. The essential oils and the herbal extracts were prepared in two different formulations and were used both in laboratory and field conditions to assess the efficiency of the formulations against the coconut mite infestation. The field trial results showed that reduction in infestation intensity was found to vary between $73.44 \%$ and $44.50 \%$ at six different locations of trial farms with an average of $64.18 \%$ after four spells of treatment. The average number of live mites was higher in the third month old nuts both in the control as well as the treated nut samples. The laboratory experiments on the efficacy of botanical biocide showed that the time taken for dehydration and shriveling of body cells took only sixty seconds. The multilocational field trials revealed the overall efficiency of the biocide to significantly control the eriophyid mite in coconut crop in an ecofriendly and sustainable manner without adopting any chemical pesticide.

\section{Introduction}

The eriophyid mite (Aceria guerreronis Keifer) is a microscopic organism that remains under the perianth of the coconut and has been one of the serious pest of coconut for the last three decades in major coconut growing countries [1-4]. These tiny mites aggregate in colonies in the inner and outer bracts and under the tepals and feed on the meristematic tissues on the nut surface. Due to mite congregation and feeding the meristematic tissue beneath the perianth becomes chlorotic and then cracks. A. guererronis infestation leads to surface scars, reduced fruit growth, and premature fruit fall [5]. The reported yield loss caused by A. guererronis was found to be $34 \%$ in India [6]. In the past few years, several studies have focused on the potential use of essential oil formulations in biological control of various insect pest and diseases. The essential oils which get more rapidly degraded into the environment than chemical compounds have been studied for their action against various insect pest of stored products [7, 8]. Recent studies have demonstrated the antilarval and antifeeding [9-11], delayed adult emergence and egg mortality [12], arrestant and repellant actions [13] of essential oils. The present study has been aimed to use these natural derivatives as an alternative ecofriendly means to control the eriophyid mites (A. guererronis Keifer), one of the serious pest of coconut.

\section{Materials and Methods}

The oils herein were chosen based on initial field studies, allowing suitable quantities of acaricides to be used more effectively over a given time interval to meet the multiple demands of efficacy, suitability to mode of application, and minimization of environmental damage. The essential 
oils and extracts from Banatulsi (Hyptis suaveolens), Tulsi (Ocimum santum), Patcholi (Pogostemon cablin), Citronella (Cymbopogon winterianus), Kalmegh (Andrographis paniculata), Citrus (Citrus limon), and Soapnut (Sapindus emarginatus) were used after analysis of their active principles against insect pest and diseases.

Field trials were conducted at five farms of coconut growing states of India (Karnataka, Kerala, West Bengal, Orissa and Andhra Pradesh (Demonstration cum-seed Production Farm (DSP) and Phillips Farm)) in replicated randomized block design. The botanical formulation in spray and herbal organic manure were applied to infested coconut plants at quarterly intervals by preparing rings to study its effectiveness against the mite. The botanical acaricide was applied on newly pollinated flowering bunches in two ways: one method consisted of spraying at the rate of $25 \mathrm{~mL}$ per flower using oil combination diluted in $250 \mathrm{~mL}$ water. Protocol two included application of $3 \mathrm{~kg}$ herbal organic manure per plant. The formulation was prepared by mixing coir pith and cow dung in a ratio of $1: 2$ along with $1 \%(\mathrm{w} / \mathrm{v})$ each of Andrographis paniculata and Hyptis suaveolens kept in a pit for three months for composting. The efficacy of the botanical biocide was based on the infestation intensity of $A$. guererronis from different farms.

To analyze competence of the botanical biocide, laboratory experiments were also conducted. The number of live mites present in nuts of different ages was studied both for control and treated plants. Nut samples from five randomly selected bunches per replication from one to six month old were collected from each of the trial farms three months after biocide application. The nuts were then subjected to counting of mites by a method according to Lawson-Balagbo et al. [14]. The mite population inside the bracts and on the nut surface below the perianth were extracted using $50 \mathrm{ml}$ of $1 \mathrm{~N}$ cetrimide solution, and the mite suspension after collection in a beaker $(100 \mathrm{~mL})$ was agitated by blowing air into it for about 15-20 seconds using a pipette for uniform mixing. Immediately, $10 \mathrm{~mL}$ of the subsample of the suspension was transferred to De Grisse counting dish, and mites were counted $(A)$. A second sample counting determined left out mites on bracts and nut surfaces $(B)$. A third count was done by direct observation of the bracts and the surface below perianth using stereoscopic microscope to count any left out mites $(C)$. Thus, the total number of mite $(N)$ present per nut was calculated by the formulae: $N=5(A+B)+C$. The samples from nuts of different ages were subjected to statistical analysis. The inflorescence was also examined for presence of eriophyid mite.

Essential oils of Hyptis suaveolens, Ocimum santum, Cymbopogon winterianus, Pogostemon cablin and Citrus limon, and botanical biocide formulation were placed in direct contact with eriophyid mite (A. guererronis). Ten live mites from each infested nuts from different farms were transferred to a cavity slide under microscope, and $20 \mu \mathrm{L}$ of the oils or formulation were applied to the slide. Time taken for dehydration and shriveling of body cells was recorded and analyzed statistically through $F$-test (Data not shown).

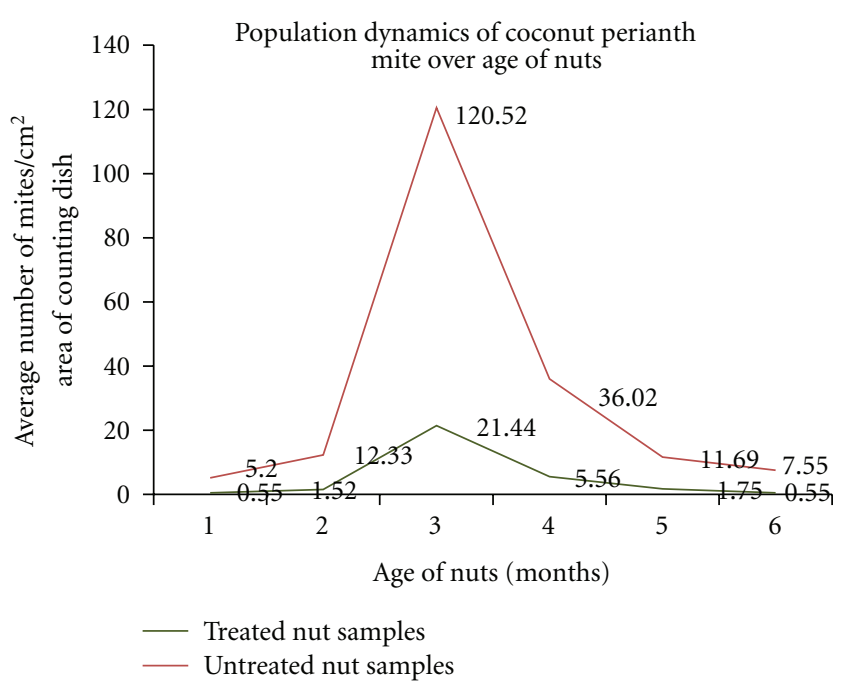

Figure 1: Effect of botanical biocide on average number of mites with respect to age of nuts.

\section{Results and Discussion}

The botanical biocide treatments against the infestation intensity of the eriophyid mite produced interesting effects (Table 1), lowering the average infestation intensity to $69.37 \%$ after six treatments. The pretreatment eriophyid intensity averaged $80.8 \%$ (range $58.2-100 \%$ ) at six trial farms. After first treatment count the botanical biocide exhibited significant effect in reducing infestation by $23.25 \%$. The percentage reduction was essentially similar at the test sites [Orissa $(35.16 \%)$, Kerala (29.96\%), Phillips farm $(23.28 \%)$, DSP farm $(22.12 \%)$, West Bengal (15.16\%), and Karnataka (13.83\%) after first treatment. After second treatment, intensity of mite in the nuts was observed to be reduced at all sites by $33.24 \%$. However, in trial farms of Karnataka and Kerala, mite infestations were higher compared to levels after previous treatments. This may be attributed to the secondary infestation of pathogens. The third treatment also increased reduction by $59.33 \%$ with a similar trend followed in the fourth treatment. Results were not significantly different at subsequent treatments. The reduction of infestation intensity in Orissa and DSP farm is significantly higher than the other trial farms (Orissa (73.44\%), DSP (71.5\%), Phillips farm (67.51\%), West Bengal $(63.94 \%$, and Karnataka (44.5\%)). The statistical analysis of fifth and sixth round of botanical biocide applications showed results at par with the fourth application, thus inferring that the application dosage of the biocide for mite control in coconut can be standardized as four applications per year for most farming locations.

The laboratory experiment for number of live mites present in nuts of different age revealed that inflorescences of coconut carried no mite. This supported the result of Moore and Alexander [15] which reports that mites do not infest the meristematic zones of unfertilized coconut flowers. The presence of mites on the nuts collected from one to sixmonth-old bunches after fertilization supported the findings 


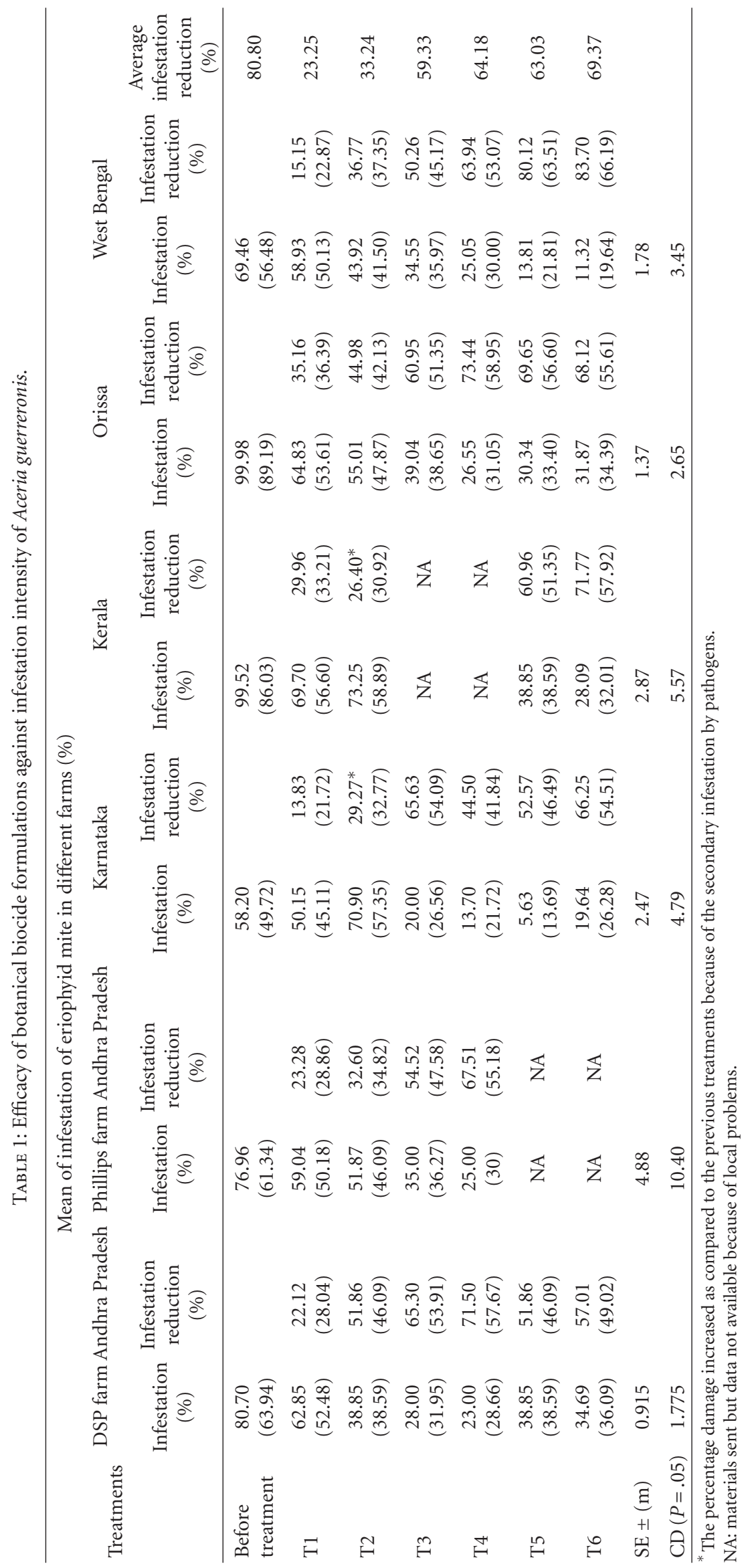




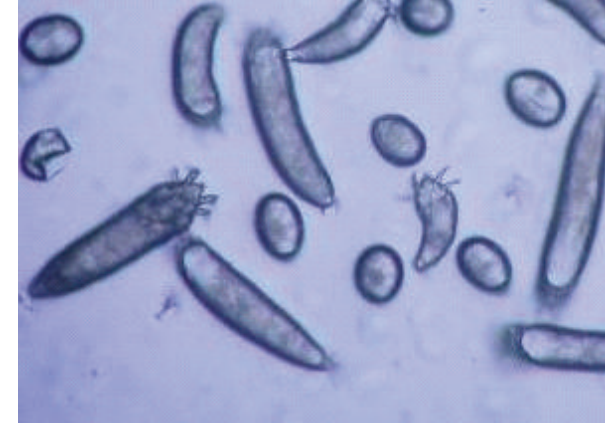

(a) Aceria guererronis Keifer before treatment.

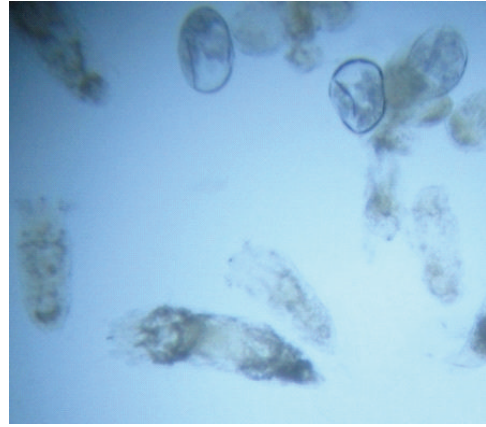

(b) Aceria guererronis Keifer after treatment.

FIGURE 2: Eriophyid mite before and after botanical biocide treatment.

of [16] where they report that after fertilization, the coconut fruits of all ages are susceptible to mite attack but in general peak mite populations occur in 3-7 months old coconuts. The highest population density of the mites was observed on the three-month-old nuts (Figure 1). Similar results on occurrence of highest number of mites on nuts of third month were reported by $[17,18]$. The laboratory studies revealed subsequent decline in number of mites with increase in age of nuts however, lowest number of mite per nut was recorded from nuts of six months. Similar report was furnished by [19] wherein mite population showed rapid increase up to an age of three months followed by steep reduction. The minimum population was being observed on nuts of age seven to eight months. However, the incidence of mites on nine to ten-month-old nuts was reported from several areas $[20,21]$. Such differences in mite population as per age of the nuts may be attributed to differences in ecological factors, age, and varieties of palms under study.

The F-test for time of dehydration of cells of E. mite showed that the treatments were significantly different from each other. The botanical biocide formulation showed best response $(60 \mathrm{sec})$ in order to cause dehydration and shriveling of cells thereby leading to death of mite (Figure 2). However, essential oil of Hyptis suaveolens $(80 \mathrm{sec}$ ) showed a par results with Cymbopogon winterianus ( $92 \mathrm{sec}$ ). The time required by the essential oils of Citrus limon $(132 \mathrm{sec})$ and Ocimum sanctum $(135 \mathrm{sec})$ were significantly not different from each other. The essential oil of Pogostemon cablin $(227 \mathrm{sec})$ took maximum time to inactivate the mite. With the treatment of biocide, the eggs were also found to degenerate along with the mite (Figure 2(b)).

\section{Conclusion}

From the significant results of the study, it can be concluded that essential oils and their constituents have varying degrees of pest controlling activities. The present study shows the possibilities of encouraging the use of botanical biocides as future pest management strategies of coconut mite.

\section{Acknowledgments}

The authors are thankful to the Coconut Development Board, Kerala, India, for its financial support, and authors are grateful to Professor B. K. Mishra, Director at IMMT for his advice, encouragement, and provision of necessary infrastructure facilities.

\section{References}

[1] R. A. Hall and B. A. Espinosa, "The coconut mite, Eriophyes guerreronis, with special reference to the problem in Mexico," in British Crop Protection Conference-Pests and Diseases, pp. 113-120, British Crop Protection Council, Farnham, UK, 1981.

[2] D. Mariau, "Aceria guerreronis: un important ravageur des cocoteraiesafricanes et americaines," Oleagineux, vol. 32, pp. 101-108, 1977.

[3] C. I. Zuluaga and P. A. Sanchez, "La rona o esoriacion de los frutosdelcocotero (Cocosnucifera L.) en Colombia," Oleagineux, vol. 26, pp. 767-770, 1971.

[4] D. Mariau and J. F. Julia, "Lacriosea Aceria guerreronis( Keifer), ravageur du cocotier," Oleagineux, vol. 28, pp. 133-135, 1970.

[5] S. E. Doreste, "El ácaro de la flordelcocotero (Aceria guerreronis Keifer) en Venezuela," Agronomia Tropical, vol. 18, pp. 370386, 1968.

[6] C. P. R. Nair, "Status of eriophyid mite, Aceriaguererronis K. in India," in Proceedings of the International Workshop on Coconut Mite, pp. 9-12, CRI, Srilanka, January 2000.

[7] E. Bazzoni, G. Sanna-Passino, and M. D. L. Moretti, "Essential oils and other control techniques against stored product insects," in Recent Progress in Medicinal Plants: Phytochemistry and Pharmacology II, D. K. Majumdar, J. N. Govil, and V. K. Singh, Eds., vol. 8, pp. 313-342, Studium Press, LLC, Houston, Tex, USA, 2002.

[8] J. B. Pillmoor, K. Wright, and A. S. Terry, "Natural products as a source of agrochemicals and leads for chemical synthesis," Journal of Pesticide Science, vol. 39, pp. 131-140, 1993.

[9] N. Larocque, C. Vincent, A. Belanger, and J. P. Bourassa, "Effects of tansy essential oil from Tanacetumvulgare on biology of oblique-banded leafroller, Choristoneura rosaceana," Journal of Chemical Ecology, vol. 25, no. 6, pp. 1319-1330, 1999. 
[10] S. J. Park, S. G. Lee, S. C. Shin, B. J. Lee, and Y. J. Ahn, "Larvicidal and antifeeding activities of oriental medicinal plant extracts against four species of forest insect pests," Applied Entomology and Zoology, vol. 32, no. 4, pp. 601-608, 1997.

[11] S. S. Bathal, D. Singh, and R. S. Dhillon, "Effect of crude root oils of Inularacemosa and Saussurealappa on feeding, survival and development of Spodopteralitura (Lepi-doptera: Noctuidae) larvae," European Journal of Entomology, vol. 90, no. 2, pp. 239-240, 1993.

[12] S. Marimuthu, G. Gurusubramanian, and S. S. Krishna, "Effect of exposure of eggs to vapours from essential oils on egg mortality, development and adult emergence in Earias vittella (F.) (lepidoptera: noctuidae)," Biological Agriculture and Horticulture, vol. 14, no. 4, pp. 303-307, 1997.

[13] P. J. Landolt, R. W. Hofstetter, and L. L. Biddick, "Plant essential oils as arrestants and repellents for neonate larvae of the codling moth (Lepidoptera: Tortricidae)," Environmental Entomology, vol. 28, no. 6, pp. 954-960, 1999.

[14] L. M. Lawson-Balagbo, M. G. C. Gondim Jr., G. L. de Moraes, R. Hanna, and P. Schausberger, "Exploration of the acarine fauna on coconut palm in Brazil with emphasis on Aceria guerreronis (Acari: Eriophyidae) and its natural enemies," Bulletin of Entomological Research, vol. 98, no. 1, pp. 83-96, 2008.

[15] D. Moore and L. Alexander, "Aspects of migration and colonization of the coconut palm by the coconut mite, E. guerreronis (Keifer) (Acari: Eriophydae)," Bulletin of Entomological Research, vol. 77, no. 4, pp. 641-650, 1987.

[16] K. Ramaraju, K. Natarajan, P. C. SundaraBabu, S. Palanisamy, and R. J. Rabindra, "Studies on coconut eriophyid mite, Aceria guerreronis Keifer in Tamil Nadu, India," in Proceedings of the International Workshop on Coconut Mite (Aceria guerreronis), L. C. P. Fernando, G. J. Moraes, and I. R. Wickramananada, Eds., pp. 13-31, Coconut Rsearch institute, Sri lanka, January 2002.

[17] C. A. Reis, J. R. Gondim, J. Gilberto et al., "Population dynamics of Aceria guerreronis Keifer (Acari: Eriophydae) and associated predators on coconut fruits in Northeast Brazil," Neotropical Entomology, vol. 37, no. 4, pp. 457-462, 2008.

[18] M. K. Varadarajan and P. M. M. David, "Population dynamics of the coconut mite Aceria guerreronis Keifer (Acari: Eriophyidae) and associated arthropods in Tamil Nadu, India," Insect Science and its Application, vol. 22, no. 1, pp. 47-59, 2002.

[19] M. A. Haq, "Coconut mite threat in Kerala," Indian Journal of Acarology, vol. 14, no. 1 \& 2, pp. 58-63, 1999.

[20] B. Sathiamma, C. P. R. Radhakrishnan Nair, and P. K. Koshi, "Outbreak of a nut infesting eriophyid mite, Eriophyes guerreronis (K.) in coconut plantations in India," Indian Coconut Journal, vol. 29, pp. 1-3, 1998.

[21] D. Moore and F. W. Howard, "Coconuts," in Eriophyid Mites: Their Biology, Natural Enemies and Control, E. F. Lindquist, M. W. Sabelis, and J. Bruin, Eds., pp. 561-570, Elsevier, Amsterdam, The Netherlands, 1996. 

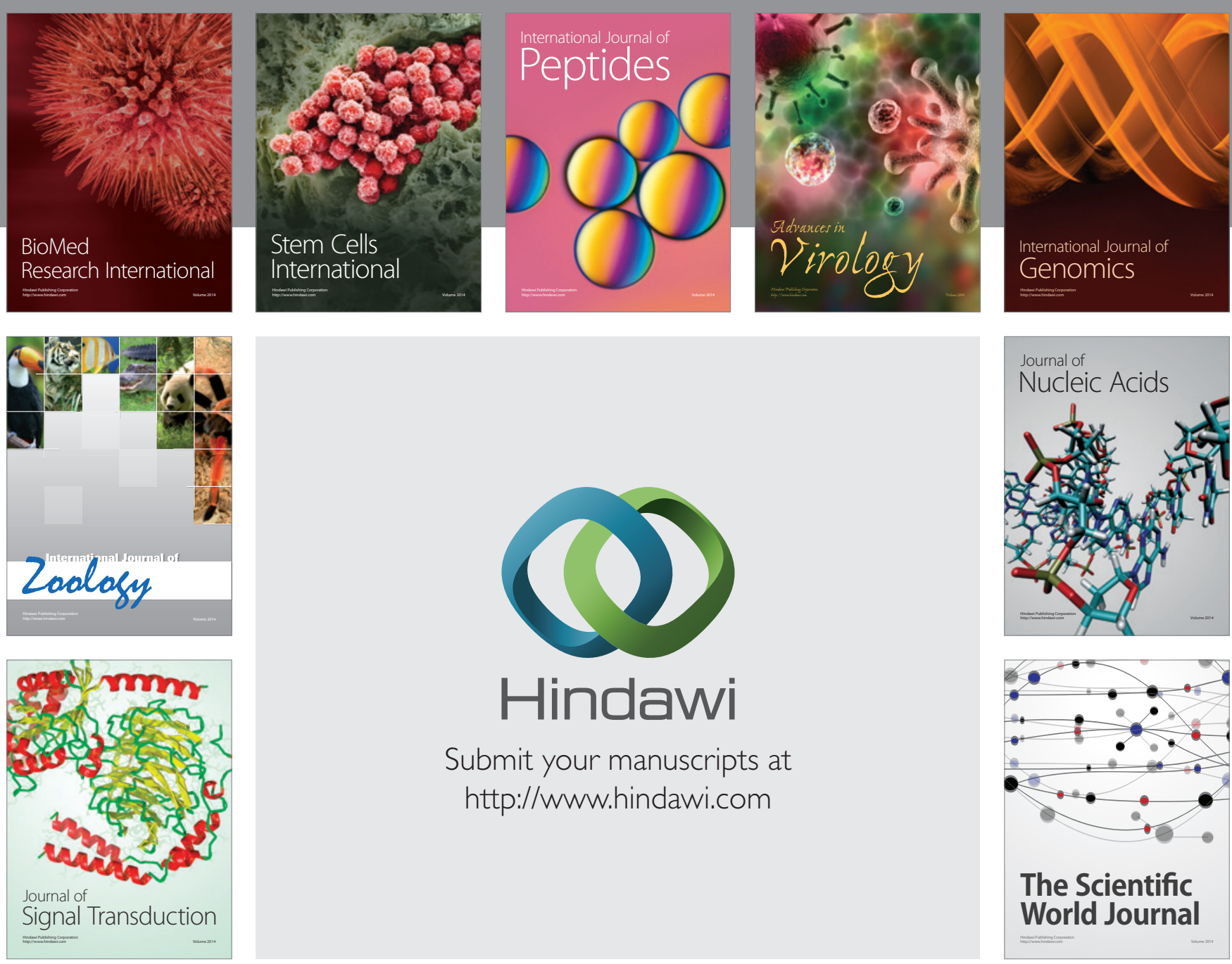

Submit your manuscripts at

http://www.hindawi.com
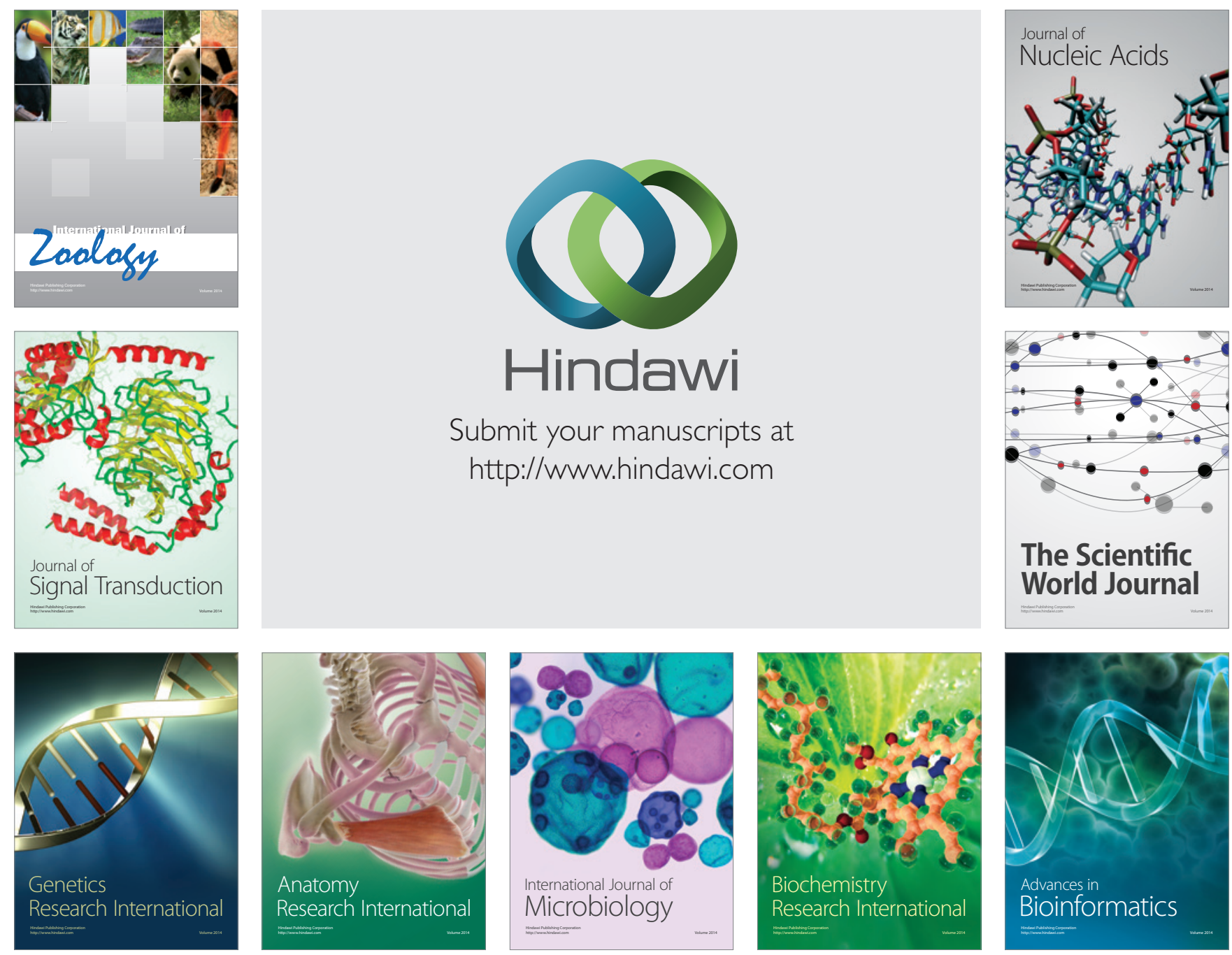

The Scientific World Journal
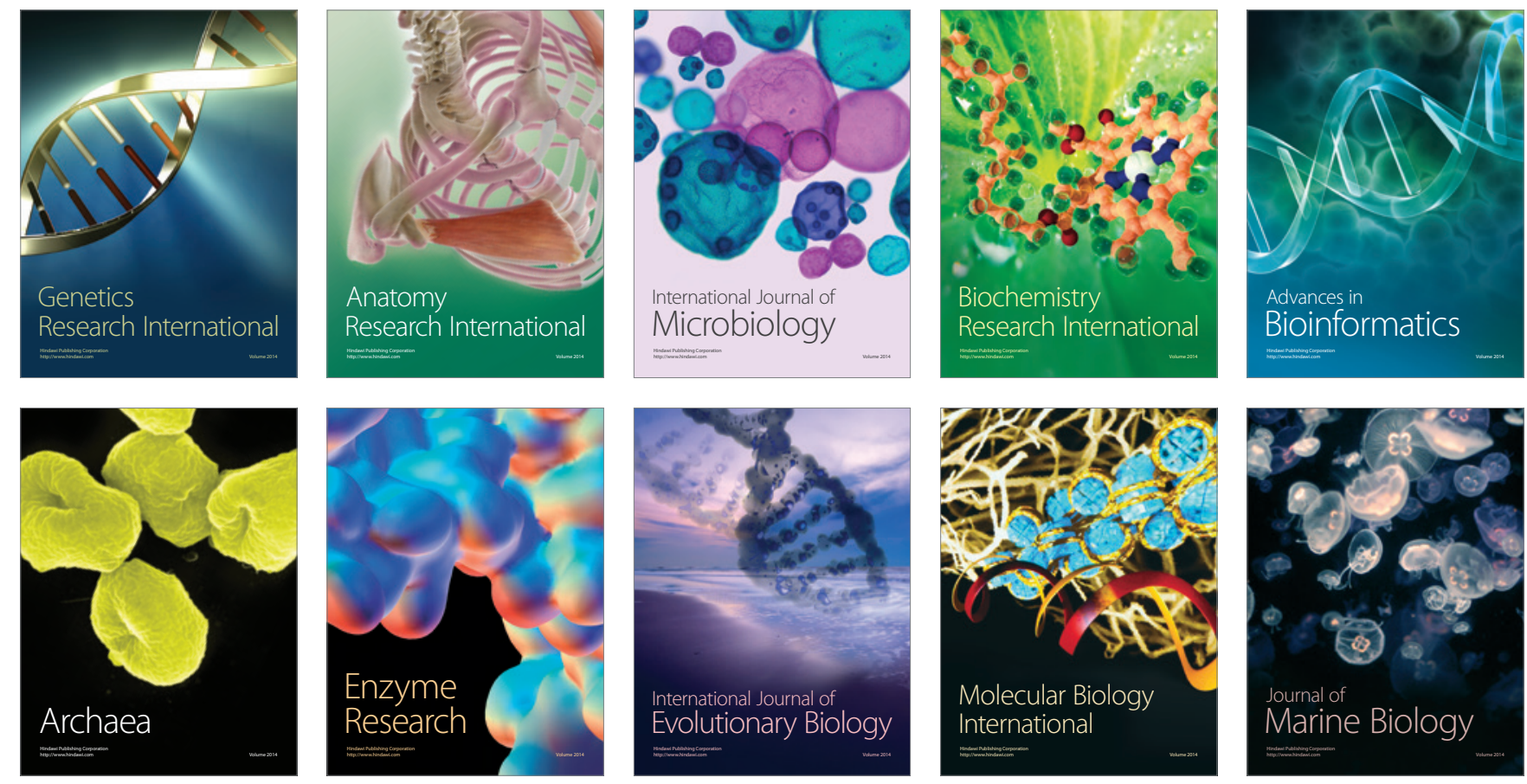